\section{Bulgarian industry tackles environment}

Bulgarian industry is involved in a crash programme of anti-pollution measures, according to $\mathbf{M r}$ Vordan Tsvetanov, Deputy Minister of Machine Building, who visited Britain recently.

The visitors, who included the Minister of Machine-Building, Mr Toncho Chakarov, came to discuss increased trade and cooperation in internal combustion engines, hydraulics and electrotechnical equipment. Although pollution problems did not enter specifically into these dscussions, $\mathrm{Mr}$ Tsvetanov told Nature that Bulgaria was making "wide use" of the anti-pollution experience of other countries and was naturally very interested in possible cooperation "especially as far as production facilities are concerned".

According to $\mathrm{Mr}$ Tsuetanov, new industrial complexes in Bulgaria pose little threat to the environment. A special government body "has a decisive say" in all matters touching on potential hazards "as early as the planning stage", deciding on the siting of the plant and the anti-pollution measures and equipment to be used. The main problem, he said, is that of existing plants which do not meet the more stringent modern requirements; Bulgarian industry is developing very rapidly and, accordingly, "everything has to be brought up to standard as soon as possible".

His own ministry, said $\mathrm{Mr}$ Tsvetanov, was particularly concerned with the purification of gaseous and liquid effluent. There is a "very substantial investment" in anti-pollution equipment, he added, "approximately 5\%" of all capital invested in industry. $\mathrm{He}$ stressed, moreover, that his ministry's work is only part of an over-all plan for environmental protection.

Asked whether Bulgaria had made any major innovations in conservation and anti-pollution measures, $\mathrm{Mr}$ Tsvetanov said that it was "very difficult to say" if Bulgaria had achieved any major breakthrough.

This was a surprisingly modest remark in view of the numerous successes announced in the Bulgarian media. During the past month, Bulgarian radio has described new closedcycle effluent-free production processes for copper, zinc, lead and molybdenum developed by the Bulgarian Academy of Sciences, a "superior" new coagulant for use in water purification, likewise from the academy, and an "efficient" method of recovering mercury from effluent, developed by the Sofia Institute of Chemical Engineering.

Vera Rich

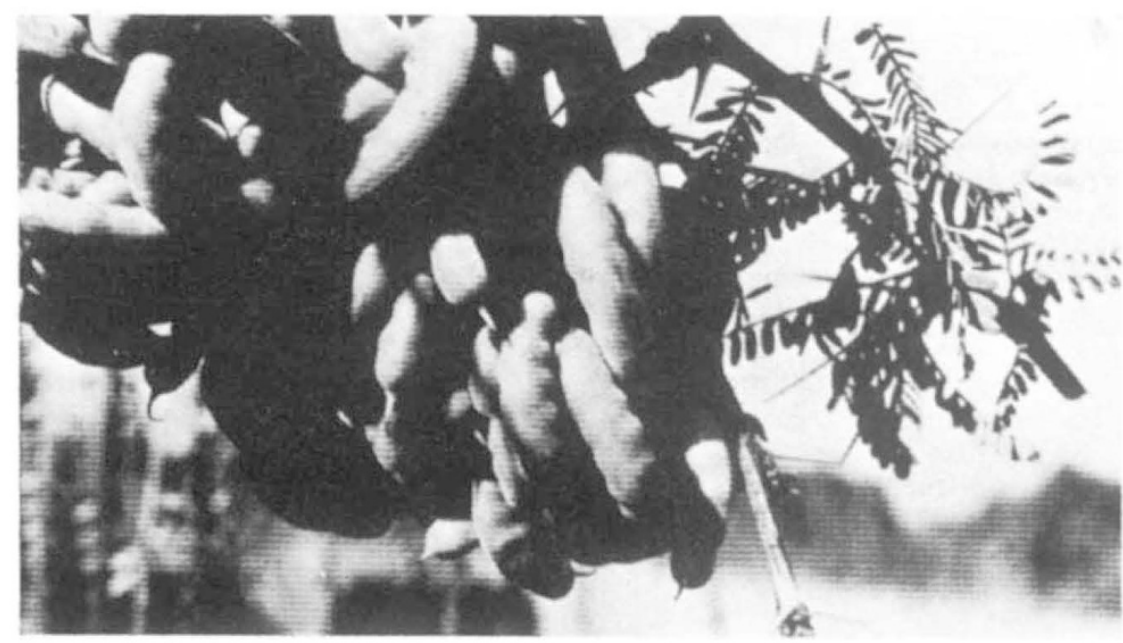

Tamarugo, a high-protein leguminous plant which survives Chile's Atacama desert. Research on species such as this could bring great benefits.

\section{"A goldmine" for scientists in third world}

"THE vast majority of agricultural research has been on north temperate species in north temperate research stations. This research has been done by the countries that need it least." Yet, $85 \%$ of all plant species grow in the tropics. This is "a goldmine of new material waiting to be worked", declared Arthur Bell, Botany Professor at King's College, London.

$\mathrm{He}$ was speaking in London Saturday at a symposium on "What kind of science for African Development?". The meeting is intended to be the first of a series run by the UK African Studies Association.

Bell also argued that research has concentrated on cereals, because they are more important in north temperate zones, whereas legumes are more important for developing countries, which are usually tropical. Legumes fix their own nitrogen, reducing the demand for chemical fertilisers, they are rich in protein, and they grow in the most inhospitable places.

Of the 17,000 species of legumes, most grow in the tropics. But few kinds of legumes are eaten, because most are toxic to man. Some have been bred over the centuries: lima or butter beans now contain less than $3 \%$ of the cyanide of their natural Javan ancestor.

He suggested that research should concentrate on already existing minor crop plants to make them more acceptable. "One can improve a plant in its own habitat with many fewer gene changes than by bringing a plant from far away in Rothamsted", UK experimental station.

One example, based on his own research, is the Lathyrus of which most species are toxic. (The common sweet pea is a Lathyrus). In India, various Lathyrus species are comomnly used

Joseph Hanlon is a development journalist specialising in third world science. for food, but if eaten in large amounts cause a paralysis of the legs known as Lathyrism. Researchers found that the toxin was oxalyldiaminopropionic acid. Bell showed that it was easy to use high voltage electrophoresis to test for this acid, and that not all Lathyrus species contained it. In a paper in Nature more than 15 years ago, he suggested that India substitute nontoxic Lathyrus species.

He now admits that this was a naive suggestion. The three commonly eaten toxic species grow well and were rich in protein. But a variation of his suggestion was adopted. Indian agricultural scientists used high voltage electrophoresis to find that there was great variation in the toxin within the species, and are now substituting less toxic varieties. Similar work has been done in Australia to make Leucaena less toxic to animals.

Bell's concern about the research bias toward the developed countries was picked up by other speakers. Indeed, the conference convener Paul Richards noted that although Bell's work was of direct use of developing countries, it was done in London rather than a developing country.

Barbara Harriss of the University of East Anglia, in a paper on the Sahel submitted to the symposium, pointed out that research funded by Western agencies tended to support particular policy aims. For example, the World Bank was looking for technological packages that the first world could export to the third. And aid donors tended to support government marketing and agricultural structures. Yet as a rule neither of these help the poorest peasants. Indeed, research has ignored what the peasants actually eat-their nutrition and preferences and what factors affect their food consumption.

Joseph Hanlon 